\title{
Analysis of APC and IGFBP7 promoter gene methylation in Swedish and Vietnamese colorectal cancer patients
}

\author{
JAN DIMBERG ${ }^{1}$, THAI TRINH HONG ${ }^{2}$, MARITA SKARSTEDT ${ }^{3}$, STURE LÖFGREN $^{3}$, \\ NIKLAS ZAR ${ }^{4}$ and ANDREAS MATUSSEK ${ }^{5}$
}

\begin{abstract}
${ }^{1}$ Department of Natural Science and Biomedicine, University College of Health Sciences, Jönköping, Sweden;
${ }^{2}$ Key Laboratory of Enzyme and Protein Technology, College of Science, Vietnam National University, Hanoi, Vietnam; Departments of ${ }^{3}$ Clinical Microbiology, ${ }^{4}$ Surgery and ${ }^{5}$ Laboratory Services, Ryhov County Hospital, Jönköping, Sweden
\end{abstract}

Received June 19, 2012; Accepted July 31, 2012

DOI: $10.3892 / \mathrm{ol} .2012 .967$

\begin{abstract}
The tumour suppressor gene adenomatous polyposis coli (APC) is a key component that drives colorectal carcinogenesis. The reported DNA methylation in the promoter of APC varies greatly among studies of colorectal cancer (CRC) in different populations. Insulin-like growth factor binding protein 7 (IGFBP7), also known as IGFBP-related protein 1 (IGFBP-rP1), is expressed in various tissue types, including the lung, brain, prostate and gastrointestinal tract, and has been suggested to play a tumour suppressor role against colorectal carcinogenesis. Studies have indicated that IGFBP7 is inactivated by DNA methylation in human colon, lung and breast cancer. In the present study, we used the methylation-specific polymerase chain reaction to study the methylation status of the APC and IGFBP7 gene promoters in cancerous and paired normal tissue to evaluate its impact on clinical factors and association with ethnicity, represented by Swedish and Vietnamese CRC patients. We also investigated the distribution of $\mathrm{CpG}$ islands and the $\mathrm{CpG}$ dinucleotide density of each $\mathrm{CpG}$ island in the regions which were the subject of our investigation. Overall, normal tissue from Swedish patients exhibited a significantly higher frequency of IGFBP7 gene methylation in comparison with that of Vietnamese patients. Moreover, a significantly higher number of cancer tissues from Vietnamese individuals showed higher levels of methylation versus the paired normal tissue compared with that of Swedish patients. When we studied the methylation in cancer compared with the matched normal tissue in individuals, we found that a significantly higher number of Vietnamese patients had a higher degree of IGFBP7 gene methylation in cancer versus matched normal tissue in comparison with Swedish patients. Taken together, our results suggest that the methylation of the APC and IGFBP7 gene promoter region in cancerous tissue, in
\end{abstract}

Correspondence to: Dr Andreas Matussek, Department of Laboratory Services, Ryhov County Hospital, Jönköping SE-551 85, Sweden

E-mail: andreas.matussek@lj.se

Key words: colorectal cancer, APC, IGFBP7, DNA methylation combination with the predominance of methylation in normal tissue, may serve as a prognostic factor in CRC patients.

\section{Introduction}

Mutations of the human tumour suppressor gene adenomatous polyposis coli (APC) are frequent in both sporadic and familial colorectal cancer (CRC) (1). Wild-type APC protein contributes to destabilisation and degradation of $\beta$-catenin, which is a central effector molecule in the Wnt/ $\beta$-catenin signalling pathway. Loss of APC function results in nuclear accumulation of $\beta$-catenin, which leads to transcriptional activation, through the $\beta$-catenin/T-cell factor complex, of target genes which may contribute to colorectal tumourigenesis $(2,3)$.

Insulin-like growth factors (IGFs), including IGF-1 and IGF-2, have been implicated in the development of CRC and their effects are regulated in part by insulin-like growth factor binding proteins (IGFBPs), which have both low and high affinity for IGFs (4). IGFBP7, also known as IGFBPrelated protein 1 (IGFBP-rP1), is widely expressed in various tissues, including the lung, brain, prostate and gastrointestinal tract (5). IGFBP7 has been shown to regulate cell proliferation, cell adhesion, differentiation and angiogenesis in various types of cancer (6-8) and plays a potential tumour suppressor role against colorectal carcinogenesis $(9,10)$. Moreover, altered expression of IGFBP7 has been demonstrated in CRC. Down- (11) and upregulation $(8,12)$ patterns compared with normal tissue have been reported.

Epigenetic modifications of DNA have been postulated to play a role in the development of multiple neoplasms in CRC $(13,14)$. DNA methylation of cytosine residues in $\mathrm{CpG}$ dinucleotides leads to transcriptional silencing of associated genes. Promoters with methylated $\mathrm{CpG}$ units, which have their transcriptional activity lowered, may function as an alternative mechanism of repressing tumour suppressor genes. The aberrant methylation of gene promoter regions has been widely studied and this epigenetic event in human malignancies may affect the cell cycle control and differentiation (13-15).

The APC promoter methylation rate has been detected in $\mathrm{CRC}$ and normal colorectal mucosa at a range of 11 to $62 \%$ in different populations, and has been suggested to moderate the Wnt signalling pathway (16-20). Studies have indicated that 
IGFBP7 is inactivated by DNA methylation in human colon, lung and breast cancer (21-23).

In the present study we used methylation-specific polymerase chain reaction (MSP) to study the methylation status of the APC and IGFBP7 genes in cancerous and paired normal tissues to evaluate its impact on clinical factors and association with ethnicity, represented by Swedish and Vietnamese CRC patients. Furthermore, we also investigated the distribution of $\mathrm{CpG}$ islands and the $\mathrm{CpG}$ dinucleotide density of each $\mathrm{CpG}$ island in the regions that were the subject of our discussion of methylation status.

\section{Materials and methods}

Patients and tissue sampling. The subjects of this study were 52 CRC patients from southeastern Sweden and 49 CRC patients from northern Vietnam. Tissue samples were collected when the patients underwent surgical resection for primary colorectal adenocarcinomas at the Department of Surgery, Ryhov County Hospital (Jönköping, Sweden) and the Department of Pathology, National Cancer Hospital (Tamhiep, Hanoi, Vietnam). Clinicopathological characteristics of the patients were obtained from surgical and pathological records. Tumour tissue and adjacent normal mucosa $(\sim 5 \mathrm{~cm}$ from the tumour) from each patient were excised and immediately frozen at $-80^{\circ} \mathrm{C}$ until analysis.

The Swedish patient group consisted of 30 males and 22 females with a mean age of 68 years (range, 29-85). The tumours were located in the colon $(n=31)$ and rectum $(n=21)$ and were classified according to the American Joint Committee on Cancer (AJCC) classification system: stage I, $\mathrm{n}=3$; stage II, $\mathrm{n}=20$; stage III, $\mathrm{n}=18$; and stage IV, $\mathrm{n}=11$. The Vietnamese patients comprised 28 males and 21 females with a mean age of 57 years (range, 26-87) and were classified as stage $I, n=26$; stage II, $n=5$; stage III, $n=17$; and stage IV, $n=1$. The tumours of the Vietnamese patients were located in the colon $(n=20)$ or rectum $(n=29)$. Informed consent was obtained from each subject and the study was approved by the ethics committee at the Faculty of Health Sciences Linköping, Sweden and by the guidelines of the local ethics committee in Vietnam

Cell lines. An established human colon cancer cell line, HT-29, was purchased from the American Type Culture Collection (ATCC, Rockville, MD, USA). The cell line was grown in the growth medium McCoy's 5A according to the supplier's instructions.

DNA extraction, bisulphite modification and MSP. DNA was isolated from tissue samples and the cell line using the QIAamp DNA Mini kit (Qiagen, Hilden, Germany). Purified DNA $(0.5 \mu \mathrm{g})$ was treated with bisulphite and purified using the EZ DNA methylation-gold kit (Zymo Research, Irvine, CA, USA) according to the manufacturer's instructions.

MSP was performed as previously described (17,23,24). The primers were synthesised commercially (TIB Molbiol, Berlin, Germany) with sequences based on a previous study $(17,23)$ as follows: APC forward, 5'-TATTGCGGAGTG CGGGTC-3' and reverse, 5'-TCGACGAACTCCCGACGA-3' for the methylated reaction (17); APC forward, 5'-GTGTTT TATTGTGGAGTGTGGGTT-3' and reverse, 5'-CCAATC
AACAAACTCCCAACAA-3' for the unmethylated reaction (17); IGFBP7 forward, 5'-AGAAATTAGAGGGTGGAA GAGTCGT-3' and reverse, 5'-CTACTAACGTCGAAA AATAAACGAA-3' for the methylated reaction (23); IGFBP7 forward, 5'-AGAAATTAGAGGGTGGAAGAGTTG-3' and reverse, 5'-CTACTAACATCAAAAAATAAACAAA-3' for the unmethylated reaction (23).

The methylated and unmethylated MSP conditions for APC were as follows: initial cycle at $95^{\circ} \mathrm{C}$ for $15 \mathrm{~min}$ followed by 35 cycles at $95^{\circ} \mathrm{C}$ for $15 \mathrm{sec}, 60^{\circ} \mathrm{C}$ for $45 \mathrm{sec}, 72^{\circ} \mathrm{C}$ for $30 \mathrm{sec}$ and final elongation at $72^{\circ} \mathrm{C}$ for $10 \mathrm{~min}$. The amplified 98 -bp product for the methylated signal and the 108-bp product for the unmethylated signal were visualised by UV-illumination on $2 \%$ agarose gel containing Gel Red (Biotium, Inc., Hayward, CA, USA).

The total volume of the PCR mixture was $25 \mu 1$ and contained $60 \mathrm{ng}$ bisulphite-modified DNA, $0.5 \mu \mathrm{M}$ of each primer (TIB Molbiol), $1.5 \mathrm{mM} \mathrm{MgCl}_{2}, 200 \mu \mathrm{M}$ of each deoxynucleotide triphosphate, 2.5 units Taq DNA polymerase and reaction buffer [20 mM Tris- $\mathrm{HCl}(\mathrm{pH} 8.3), 20 \mathrm{mM} \mathrm{KCl}, 5 \mathrm{mM}$ $\left(\mathrm{NH}_{4}\right)_{2} \mathrm{SO}_{4}$ (Fermentas, Burlington, Canada)].

The methylated and unmethylated MSP conditions for IGFBP7 were as follows: initial cycle at $95^{\circ} \mathrm{C}$ for $4 \mathrm{~min}$ followed by 8 cycles at $95^{\circ} \mathrm{C}$ for $2 \mathrm{~min}, 60^{\circ} \mathrm{C}$ for $30 \mathrm{sec}, 72^{\circ} \mathrm{C}$ for $30 \mathrm{sec} ; 32 \mathrm{cycles}$ of $95^{\circ} \mathrm{C}$ for $30 \mathrm{sec}, 60^{\circ} \mathrm{C}$ for $30 \mathrm{sec}, 72^{\circ} \mathrm{C}$ for $30 \mathrm{sec}$ and then a final elongation at $72^{\circ} \mathrm{C}$ for $5 \mathrm{~min}$. The amplified 173-bp products for both methylated and unmethylated signals were visualised by UV-illumination on $2 \%$ agarose gel containing Gel Red (Biotium, Inc.).

The total volume of the PCR mixture was $25 \mu 1$ and contained $60 \mathrm{ng}$ bisulphite-modified DNA, $0.35 \mu \mathrm{M}$ of each primer (TIB Molbiol), $1.5 \mathrm{mM} \mathrm{MgCl}_{2}, 200 \mu \mathrm{M}$ of each deoxynucleotide triphosphate, 2.5 units Taq DNA polymerase and reaction buffer [20 mM Tris- $\mathrm{HCl}(\mathrm{pH} 8.3), 20 \mathrm{mM} \mathrm{KCl}, 5 \mathrm{mM}$ $\left(\mathrm{NH}_{4}\right)_{2} \mathrm{SO}_{4}$ (Fermentas)].

CpG island analysis. Using RefSeqGene of APC (GenBank: NG_008481.4) and (GenBank: NG_031877.1) all potential transcription start sites (TSSs) were identified. Then 3,000 bp, including 2,000 bp of sequence extending from the 5' upstream region to $1,000 \mathrm{bp}$ downstream of the TSS, were selected to submit to the MethPrimer (25) and cpgplot programmes (EMBOSS) (26) for analysis of the CpG islands.

Promoter prediction. The 3,000-bp sequence of the IGFBP7 gene (GenBank: NG_031877.1) was entered into the programmes of FirstEF (27) and Proscan (28) for its promoter prediction.

Statistical analysis. The Chi-square test was used to investigate the difference in the methylation status of the groups. Statistical analyses were performed using SPSS for Windows computer package (Rel. 14.0, SPSS Inc., Chicago, IL, USA, 2005). $\mathrm{P}<0.05$ was considered to indicate a statistically significant result.

\section{Results}

Distribution of $C p G$ islands in selected region of the APC and IGFBP7 genes. Using the MethPrimer and cpgplot programmes, 4 CpG islands around TSS-1 (NM_001127511.1) 

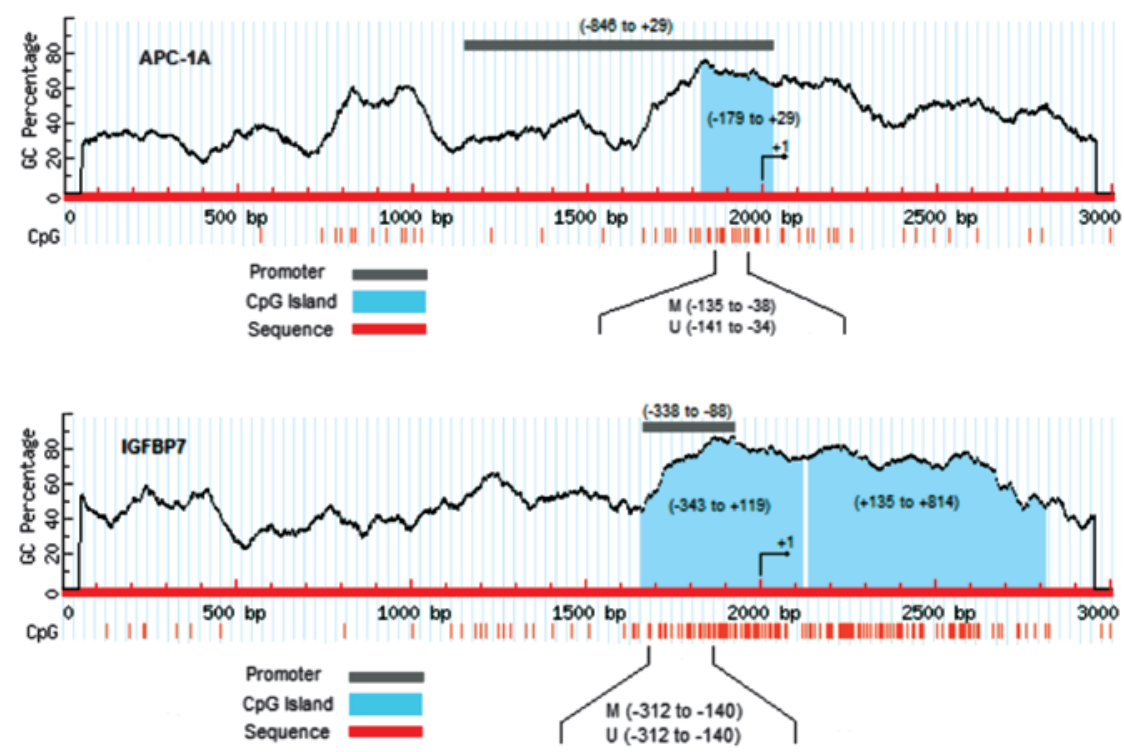

Figure 1. Bioinformatic analysis of APC and IGFBP7 genes. Location of CpG islands (light blue), promoter regions (grey) and MSP-amplified regions for methylated $(\mathrm{M})$ and unmethylated $(\mathrm{U})$ sequences. Indicated positions are relative to the transcription start site $(+1)$. MSP, methylation-specific polymerase chain reaction; APC, adenomatous polyposis coli; IGFBP7, insulin-like growth factor binding protein 7.

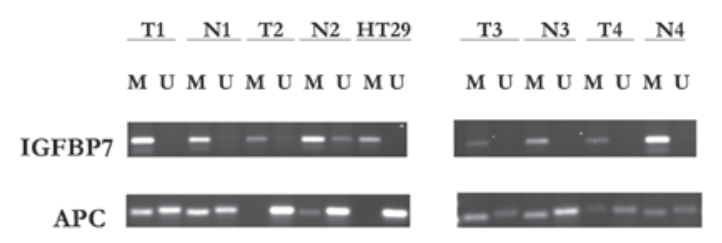

Figure 2. Methylation status of the IGFBP7 and APC genes detected by MSP in the HT-29 cell line, two CRC patients from Vietnam (cases 1 and 2) and two patients from Sweden (cases 3 and 4). The PCR products in the lanes $\mathrm{M}$ and $\mathrm{U}$ indicate the presence of methylated and unmethylated fragments, respectively. T, tumour; $\mathrm{N}$, normal paired tissue. MSP, methylation-specific polymerase chain reaction; IGFBP7, insulin-like growth factor binding protein 7; APC, adenomatous polyposis coli.

and 1 CpG island around TSS-2-3 (NM_001127510.1 and NM_000038.4) were determined for the APC gene. The result of the $\mathrm{CpG}$ island analysis for the IGFBP7 gene was $2 \mathrm{CpG}$ islands (Fig 1).

In order to study promoter methylation, the promoter sequences were searched in the nucleotide database. The APC promoter sequence was found in GenBank (U02509). However, the IGFBP7 gene promoter was not found, therefore we predicted the promoter using two programmes (FirstEF and Proscan). The predicted result of the IGFBP7 promoter sequence was from -338 to -88 (Proscan) and -333 to +237 (FirstEF) in the positions relative to the TSS $(+1)$.

In comparison of the $\mathrm{CpG}$ islands and promoter sequences, the $\mathrm{CpG}$ island of the APC gene in position -179 to +29 is located within the $1 \mathrm{~A}$ promoter region (accession No. U02509) and the $\mathrm{CpG}$ island of the IGFBP7 gene in position -343 to +119 is located in the predicted promoter region of the IGFBP7 gene. Therefore, DNA sequences of these islands were used as templates for MSP analysis (Fig. 1).

$A P C$ and IGFBP7 methylation status in CRC tissues and paired normal tissues. An MSP assay was performed for APC in tissues from 52 Swedish CRC patients and 49 Vietnamese CRC patients and for IGFBP7 in 51 of the tissues from the Swedish patients and 48 of the Vietnamese patients. Representative band profiles of the MSP reactions of the APC and IGFBP7 are illustrated in Fig. 2. Methylated (M) and unmethylated (U) signals of the IGFBP7 and APC genes were detected in HT-29 cells and colorectal tissue (Fig. 2).

For APC, no biallelic methylation (M/M) signals were detected in colorectal tissue either in Swedish or Vietnamese patients (Table I). However, the groups exhibited a pattern that included both monoallelic methylation $(\mathrm{M} / \mathrm{U})$ and biallelic unmethylation (U/U; Table I).

With regard to the IGFBP7 gene, we observed each combination of methylation and unmethylation status in all tissue samples from the two groups, with the exception of the combination $\mathrm{U} / \mathrm{U}$ in normal tissue from Swedish patients (Table I).

In the cancerous tissue from Swedish patients, methylation in the APC and IGFBP7 genes was detected in $53.8(28 / 52)$ and $88.2 \%(45 / 51)$ of the samples, respectively. In cancerous tissue from Vietnamese patients, the methylation rate in the APC and IGFBP7 genes was 44.9 (22/49) and 89.6\% (43/48), respectively (Table I).

The methylation rates of the APC and IGFBP7 genes in normal tissue from Swedish patients were 71.1 (37/52) and $100 \%$ (51/51), respectively. APC and IGFBP7 gene methylation in the normal tissue of Vietnamese patients was present in 59.2 $(29 / 49)$ and $89.6 \%$ (43/48) of samples, respectively (Table I).

Overall, the difference in methylation frequency between cancerous and normal tissue within and between the ethnic groups was not statistically significant for APC or IGFBP7, with the exception of the normal tissue from Swedish patients, which exhibited a significantly $(\mathrm{P}<0.05)$ higher frequency $[100 \%(51 / 51)]$ of methylation of the IGFBP7 gene in comparison with the normal tissue from Vietnamese patients $[89.6 \%$ (43/48; Table I)]. 
Table I. Prevalence of APC and IGFBP7 DNA gene methylation (M) and unmethylation (U) in CRC tissue and matched normal tissue in Swedish and Vietnamese patients.

\begin{tabular}{lccc}
\hline Gene and tissue & M/M & M/U & U/U \\
\hline APC & & & \\
$\quad$ Swedish patients $(\mathrm{n}=52)$ & & & \\
$\quad$ Cancer tissue & 0 & 37 & 15 \\
$\quad$ Normal tissue & 0 & & \\
Vietnamese patients $(\mathrm{n}=49)$ & & 22 & 27 \\
$\quad$ Cancer tissue & 0 & 29 & 20 \\
$\quad$ Normal tissue & 0 & & \\
IGFBP7 & & & \\
Swedish patients $(\mathrm{n}=51)$ & 25 & 20 & 6 \\
$\quad$ Cancer tissue & 22 & 29 & 0 \\
$\quad$ Normal tissue & & \\
$\quad$ Vietnamese patients $(\mathrm{n}=48)$ & & 23 & 5 \\
$\quad$ Cancer tissue & 20 & 27 & 5 \\
$\quad$ Normal tissue & 16 &
\end{tabular}

APC, adenomatous polyposis coli; IGFBP7, insulin-like growth factor binding protein 7; CRC, colorectal cancer.

When we studied the individual methylation in cancer relative to the matched normal tissue, we found that 7 Swedish patients had a higher degree of methylation of the IGFBP7 gene in cancer tissue than the corresponding normal tissue. When the same comparison was made in Vietnamese patients, we found that 17 patients showed a higher degree of methylation in cancer versus matched normal tissue (Table II). The difference between the ethnic groups was significant $(\mathrm{P}<0.05)$. A similar comparison was made of the methylation of the APC gene, in which we found that 7 Swedish and 8 Vietnamese patients showed a higher degree of methylation in cancer than in matched normal tissue, but the difference was not significant.

There was no statistically significant association between MSP findings with other clinical parameters, including gender, age, location or stage (data not shown).

\section{Discussion}

Epigenomic instability has been postulated to play a role in the development of multiple types of neoplasia, including CRC $(13,14)$. The methylation of gene promoter regions has been widely studied and this epigenetic event affects cell cycle control and differentiation in human malignancies. Previous studies have reported that the aberrant hypermethylation of promoter $\mathrm{CpG}$ islands is linked to gene silencing and loss of tumour suppressor function (13-15).

The tumour suppressor gene APC is one of the key components of the Wnt pathway (3). The reported methylation status of the promoter of APC varies greatly among studies of CRC in different populations (16-20). Moreover, hypermethylation of the APC promoter has been shown to be relatively common
Table II. Distribution of methylation (M) and unmethylation (U) of APC and IGFBP7 genes in CRC tissues compared with matched normal tissue from Swedish and Vietnamese patients.

\begin{tabular}{|c|c|c|c|}
\hline \multirow[b]{2}{*}{ Gene and tissue } & \multicolumn{3}{|c|}{ Normal tissue } \\
\hline & $\mathrm{M} / \mathrm{M}$ & $\mathrm{M} / \mathrm{U}$ & $\mathrm{U} / \mathrm{U}$ \\
\hline \multicolumn{4}{|l|}{ APC } \\
\hline \multicolumn{4}{|c|}{ Swedish patients $(\mathrm{n}=52)$} \\
\hline \multicolumn{4}{|l|}{ Cancer tissue } \\
\hline $\mathrm{M} / \mathrm{M}(\mathrm{n}=0)$ & 0 & 0 & 0 \\
\hline $\mathrm{M} / \mathrm{U}(\mathrm{n}=28)$ & 0 & 21 & 7 \\
\hline $\mathrm{U} / \mathrm{U}(\mathrm{n}=24)$ & 0 & 16 & 8 \\
\hline \multicolumn{4}{|c|}{ Vietnamese patients $(n=49)$} \\
\hline \multicolumn{4}{|l|}{ Cancer tissue } \\
\hline $\mathrm{M} / \mathrm{M}(\mathrm{n}=0)$ & 0 & 0 & 0 \\
\hline $\mathrm{M} / \mathrm{U}(\mathrm{n}=22)$ & 0 & 14 & 8 \\
\hline $\mathrm{U} / \mathrm{U}(\mathrm{n}=27)$ & 0 & 15 & 12 \\
\hline \multicolumn{4}{|l|}{ IGFBP7 } \\
\hline \multicolumn{4}{|c|}{ Swedish patients $(\mathrm{n}=51)$} \\
\hline \multicolumn{4}{|l|}{ Cancer tissue } \\
\hline $\mathrm{M} / \mathrm{M}(\mathrm{n}=25)$ & 18 & 7 & 0 \\
\hline $\mathrm{M} / \mathrm{U}(\mathrm{n}=20)$ & 2 & 18 & 0 \\
\hline $\mathrm{U} / \mathrm{U}(\mathrm{n}=6)$ & 2 & 4 & 0 \\
\hline \multicolumn{4}{|c|}{ Vietnamese patients $(n=48)$} \\
\hline \multicolumn{4}{|l|}{ Cancer tissue } \\
\hline $\mathrm{M} / \mathrm{M}(\mathrm{n}=20)$ & 6 & 12 & 2 \\
\hline $\mathrm{M} / \mathrm{U}(\mathrm{n}=23)$ & 6 & 14 & 3 \\
\hline $\mathrm{U} / \mathrm{U}(\mathrm{n}=5)$ & 4 & 1 & 0 \\
\hline
\end{tabular}

APC, adenomatous polyposis coli; IGFBP7, insulin-like growth factor binding protein 7; CRC, colorectal cancer.

in other gastrointestinal neoplasms, including those of the stomach, liver, pancreas and oesophagus $(17,29)$.

In the Swedish and Vietnamese CRC patients, methylation of the APC gene was detected without any significant difference between the cancerous and normal tissues within or between the ethnic groups. In agreement with the results of previous studies $(30,31)$, we also noted that the colon cancer cell line HT-29 shows APC gene hypomethylation status.

IGFBP7 plays a potential tumour suppressor role against colorectal carcinogenesis $(9,10)$. The molecular mechanism by which IGFBP7 contributes to tumour suppression is not fully understood. Altered expression of IGFBP7 compared with normal tissue has been noted $(8,11,12)$ and higher tissue expression indicates favorable prognosis (10). However, these facts contradict the results of Adachi et al, who found IGFBP7 expression to be correlated with a poor prognosis (32). Studies have indicated that the IGFBP7 gene is inactivated by DNA methylation in human colon, lung and breast cancer (21-23). In agreement with previous observations $(11,33)$, we found that the colon cancer cell line HT-29 shows IGFBP7 gene hypermethylation status. No significant difference was 
obtained when we compared the IGFBP7 gene methylation frequency between CRC tissue from Swedish and Vietnamese patients. However, the normal tissue from Swedish patients exhibited a significantly higher frequency of IGFBP7 gene methylation compared with the normal tissue of Vietnamese patients. Moreover, a significant number of cancer tissues from Vietnamese individuals showed higher levels of methylation versus the paired normal tissue compared with that of the Swedish patients. It is possible that this subset of patients had another disease progression or that the result is due to the definition of histologically normal tissue.

When we studied the individual methylation in cancer compared with the matched normal tissue, we found that certain Swedish patients had a higher degree of methylation in cancer tissue than the corresponding normal tissue with respect to IGFBP7. When the same comparison was made with Vietnamese patients, we found a significantly higher number of patients with higher degree of methylation in cancer versus matched normal tissue.

In the present study, a number of patients had a high degree of methylation of the normal tissue. However, epigenetic alterations are commonly observed not only in cancer tissues but also in non-cancerous tissues, as has been noted in the stomach (34) and colon (35). Such phenomena may be explained by the 'field cancerisation' caused by carcinogen exposure (35). In our case, this may be explained by the influence of inflammatory mediators, as inflammation has been shown to accelerate DNA methylation in normal tissues (36).

In Vietnam, malignancies of the gastrointestinal tract are common in the stomach and liver but are comparatively less frequent in the colon and rectum (37). The incidence of CRC is rapidly rising in Asian countries and is beginning to exhibit the same rate as in Western countries (38). However, there remains a difference in the incidence of CRC between Vietnam and Western countries (38). As part of efforts to increase our understanding of this difference and reflect molecular pathological differences, we chose to consider the epigenetic aspects of CRC. To the best of our knowledge, this is the first time that the methylation status of the APC and IGFBP7 genes has been analysed in Vietnamese CRC patients.

Taken together, our results suggest that hypermethylation of the APC and IGFBP7 gene promoter region in cancerous and normal tissue may be a prognostic factor in CRC patients. We are aware that our finding needs to be confirmed by extended studies before drawing a final conclusion regarding these suggestions. Moreover, the data presented in this study are prerequisite to a forthcoming study of $\mathrm{CRC}$ patients to evaluate the influence of APC and IGFBP7 gene methylation status in cancer and normal tissue on 5-year survival and recurrence rates.

\section{Acknowledgements}

We thank Dr Tran Van Tuan at the Department of Cytology and Pathology, National Cancer Hospital, Tam Hiep, Hanoi, Vietnam for providing us with tissue from Vietnamese colorectal cancer patients. This study was supported by grants from the Foundation of Clinical Cancer Research, Jönköping, Sweden and grant from the project KLEPT-09-02, College of Science, Vietnam National University, Hanoi, Vietnam.

\section{References}

1. Miyoshi Y, Nagase H, Ando H, Horii A, Ichii S, Nakatsuru S, Aoki T, Miki Y, Mori T and Nakamura Y: Somatic mutations of the APC gene in colorectal tumors: mutation cluster region in the APC gene. Hum Mol Genet 1: 229-233, 1992.

2. Morin PJ, Sparks AB, Korinek V, Barker N, Clevers H, Vogelstein B and Kinzler KW: Activation of beta-catenin-Tcf signaling in colon cancer by mutations in beta-catenin or APC. Science 275: 1787-1790, 1997.

3. Schneikert J and Behrens J: The canonical Wnt signalling pathway and its APC partner in colon cancer development. Gut 56: 417-425, 2007.

4. Durai R, Yang W, Gupta S, Seifalian AM and Winslet MC: The role of the insulin-like growth factor system in colorectal cancer: review of current knowledge. Int J Colorectal Dis 20: 203-220, 2005.

5. Degeorges A, Wang F, Frierson HF Jr, Seth A and Sikes RA: Distribution of IGFBP-rP1 in normal human tissues. J Histochem Cytochem 48: 747-754, 2000.

6. Burger AM, Leyland-Jones B, Banerjee K, Spyropoulos DD and Seth AK: Essential roles of IGFBP-3 and IGFBP-rP1 in breast cancer. Eur J Cancer 41: 1515-1527, 2005.

7. Sato Y, Chen Z and Miyazaki K: Strong suppression of tumor growth by insulin-like growth factor-binding protein-related protein 1/tumor-derived cell adhesion factor/mac25. Cancer Sci 98: 1055-1063, 2007.

8. Georges RB, Adwan H, Hamdi H, Hielscher T, Linnemann U and Berger MR: The insulin-like growth factor binding proteins 3 and 7 are associated with colorectal cancer and liver metastasis. Cancer Biol Ther 12: 69-79, 2011.

9. Ruan WJ, Lin J, Xu EP, Xu FY, Ma Y, Dengh H, Huang Q, Lv BJ, $\mathrm{Hu} \mathrm{H}$, Cui J, Di MJ, Dong JK and Lai MD: IGFBP7 plays a potential tumor suppressor role against colorectal carcinogenesis with its expression associated with DNA hypomethylation of exon 1. J Zhejiang Univ Sci B 7: 929-932, 2006.

10. Ruan W, Xu E, Xu F, Ma Y, Deng H, Huang Q, Lv B, Hu H, Lin J, Cui J, Di M, Dong J and Lai M: IGFBP7 plays a potential tumor suppressor role in colorectal carcinogenesis. Cancer Biol Ther 6: 354-359, 2007.

11. Ye F, Chen Y, Knösel T, Schluns K, Pacyna-Gengelbach M, Deutschmann N, Lai M and Petersen I: Decreased expression of insulin-like growth factor binding protein 7 in human colorectal carcinoma is related to DNA methylation. J Cancer Res Clin Oncol 133: 305-314, 2007.

12. Mälarstig A, Wågsäter D, Löfgren S, Hugander A, Zar N and Dimberg J: Tumor-derived adhesion factor in colorectal cancer. Mol Med Rep 2: 971-976, 2009.

13. Kondo Y and Issa JP: Epigenetic changes in colorectal cancer. Cancer Metastasis Rev 23: 29-39, 2004.

14. Venkatachalam R, Ligtenberg MJ, Hoogerbrugge $N$, de Bruijn DR, Kuiper RP and Geurts van Kessel A: The epigenetics of (hereditary) colorectal cancer. Cancer Genet Cytogenet 203: 1-6, 2010.

15. Jones PA and Baylin SB: The epigenomics of cancer. Cell 128: 683-692, 2007.

16. Naghibalhossaini F, Zamani M, Mokarram P, Khalili I, Rasti M and Mostafavi-Pour Z: Epigenetic and genetic analysis of WNT signaling pathway in sporadic colorectal cancer patients from Iran. Mol Biol Rep 39: 6171-6178, 2012.

17. Esteller M,Sparks A, Toyota M, Sanchez-Cespedes M, Capella G, Peinado MA, Gonzales S, Tarafa G, Sidransky D, Meltzer SJ, Baylin SB and Herman JG: Analysis of adenomatous polyposis coli promoter hypermethylation in human cancer. Cancer Res 60: 4366-4371, 2000.

18. Lee S, Hwang KS, Lee HJ, Kim JS and Kang GH: Aberrant $\mathrm{CpG}$ island hypermethylation of multiple genes in colorectal neoplasia. Lab Invest 84: 884-893, 2004.

19. Lee BB, Lee EJ, Jung EH, Chun HK, Chang DK, Song SY, Park J and Kim DK: Aberrant methylation of APC, MGMT, RASSF2A and Wif-1 genes in plasma as a biomarker for early detection of colorectal cancer. Clin Cancer Res 15: 6185-6191, 2009.

20. Chen SP, Chiu SC, Wu CC, Lin SZ, Kang JC, Chen YL, Lin PC, Pang CY and Harn HJ: The association of methylation in the promoter of APC and MGMT and the prognosis of Taiwanese CRC patients. Genet Test Mol Biomarkers 13: 67-71, 2009.

21. Lin J, Lai M, Huang Q, Ruan W, Ma Y and Cui J: Reactivation of IGFBP7 by DNA demethylation inhibits human colon cancer cell growth in vitro. Cancer Biol Ther 7: 1896-1900, 2008. 
22. Chen Y, Cui T, Knösel T, Yang L, Zöller K and Petersen I: IGFBP7 is a 533 target gene inactivated in human lung cancer by DNA hypermethylation. Lung Cancer 73: 38-44, 2011.

23. Smith P, Nicholson LJ, Syed N, Payne A, Hiller L, Garrone O, Occelli M, Gasco M and Crook T: Epigenetic inactivation implies independent functions for insulin-like growth factor binding protein (IGFBP)-related protein 1 and related IGFBPL1 in inhibiting breast cancer phenotypes. Clin Cancer Res 13: 4061-4068, 2007.

24. Herman JG, Graff JR, Myöhänen S, Nelkin BD and Baylin SB: Methylation-specific PCR: A novel PCR assay methylation status of CpG islands. Proc Natl Acad Sci USA 93: 9821-9826, 1996.

25. Li LC and Dahiya R: MethPrimer: designing primers for methylation PCRs. Bioinformatics 18: 1427-1431, 2002.

26. Rice P, Longden I and Bleasby A: EMBOSS: The European Molecular Biology Open Software Suite. Trends Genet 16 276-277, 2000

27. Davuluri RV, Grosse I and Zhang MQ: Computational identification of promoters and first exons in the human genome. Nat Genet 29: 412-417, 2001.

28. Prestridge DS: Predicting Pol II promoter sequences using transcription factor binding sites. J Mol Biol 249: 923-932, 1995.

29. Clément G, Bosman FT, Fontolliet C and Benhattar J: Monoallelic methylation of the APC promoter is altered in normal gastric mucosa associated with neoplastic lesions. Cancer Res 64: 6867-6873, 2004.

30. Sakamoto Y, Kitazawa R, Maeda S and Kitazawa S: Methylation of $\mathrm{CpG}$ loci in 5'-flanking region alters steady-state expression of adenomatous polyposis coli gene in colon cancer cell lines. J Cell Biol 80: 415-423, 2001.

31. Lind GE, Thorstensen L, Løvig T, Meling GI, Hamelin R, Rognum TO, Esteller M and Lothe RA: A CpG island hypermetylation profile of primary colorectal carcinomas and colon cancer cell lines. Mol Cancer 3: 28, 2004.
32. Adachi Y, Itoh F, Yamamoto H, Arimura Y, Kikkawa-Okabe Y, Miyazaki K, Carbone DP and Imai K: Expression of angiomodulin (tumor-derived adhesion factor/mac25) in invading tumor cells correlates with poor prognosis in human colorectal cancer. Int J Cancer 95: 216-222, 2001.

33. Lin J, Lai M, Huang Q, Ma Y, Cui J and Ruan W: Methylation patterns of IGFBP7 in colon cancer cell lines are associated with levels of gene expression. J Pathol 212: 83-90, 2007.

34. Nakajima T, Maekita T, Oda I, Gotoda T, Yamamoto S, Umemura S, Ichinose M, Sugimura T, Ushijima T and Saito D: Higher methylation levels in gastric mucosae significantly correlate with higher risk of gastric cancer. Cancer Epidemiol Biomarkers Prev 15: 2317-2321, 2006.

35. Shen L, Kondo Y, Rosner GL, Xiao L, Hernandez NS Vilaythong J, Houlihan PS, Krouse RS, Prasad AR, Einspahr JG, Buckmeier J, Alberts DS, Hamilton SR and Issa JPJ: MGMT promoter methylation and field defect in sporadic colorectal cancer. J Natl Cancer Inst 97: 1330-1338, 2005.

36. Issa JP, Ahuja N, Toyota M, Bronner MP and Brentnall TA: Accelerated age-related $\mathrm{CpG}$ island methylation in ulcerative colitis. Cancer Res 61: 3573-3577, 2001.

37. Anh PT and Duc NB: The situation with cancer control in Vietnam. Jpn J Clin Oncol 32 (Suppl): S92-S97, 2002

38. Sung JJ, Lau JY, Young GP, Sano Y, Chiu HM, Byeon JS, Yeoh KG, Goh KL, Sollano J, Rerknimitr R, Matsuda T, Wu KC, Ng S, Leung SY, Makharia G, Chong VH, Ho KY, Brooks D, Lieberman DA and Chan FK; Asia Pacific Working Group on Colorectal Cancer: Asia Pacific consensus recommendations for colorectal cancer screening. Gut 57: 1166-1176, 2008. 